\title{
Ammonia removal from giant fresh water prawn farm by using zeolite from oil palm ash
}

\author{
Rewadee Anuwattana ${ }^{1,}$, Pattamaphorn Phungngamphan ${ }^{1}$, Patthanant Natpinit $^{1}$, Narumon Soparatana ${ }^{1}$, \\ Worapong Pattayawan ${ }^{1}$, and Supinya Yindee $^{1}$
}

${ }^{1}$ Expert Centre of Innovative Clean Energy and Environment, Thailand Institute of Scientific and Technological Research (TISTR) 35Mu 3, Technopolis, Khlong 5, Khlong Luang, Pathum Thani 12120, Thailand.

\begin{abstract}
The Empty Fruit Bunch (EFB) and Mesocarp fiber ash (FB) was obtained from the boiler at NAM HONG Palm Oil Company Limited, Thailand. The optimum condition was used in Na-A zeolite synthesis from oil palm ash. The obtain produce was $\mathrm{Na}_{12} \mathrm{Al}_{12} \mathrm{Si}_{12} \mathrm{O}_{48} \cdot 27 \mathrm{H}_{2} \mathrm{O}$. The sample was dried in hot air oven. The calcium exchange capacity (CEC) of $386.39 \mathrm{mg} \mathrm{CaCO}_{3} / \mathrm{g}$ of product, and the $86.05 \%$ of pure $\mathrm{Na}-\mathrm{A}$ zeolite phase was formed. In batch experimental study, the synthetic wastewater was prepared. In order to find out the optimal zeolite dosage was added into $10 \mathrm{mg} / \mathrm{L}$ of total ammonium nitrogen solution. The results of unionized ammonia $\left(\mathrm{NH}_{3}\right)$ removal efficiency indicated that zeolite A standard and zeolite from oil palm ash are better than commercial zeolite. The optimum dosage of $0.2,0.25$ and $0.2 \mathrm{~g}$ of zeolite A standard, zeolite from oil palm ash and commercial zeolite, respectively. The $\mathrm{NH}_{3}$ removal capacity from giant freshwater prawn farm, zeolite A standard is better than zeolite from oil palm ash and commercial zeolite, respectively. In the large volume of synthetic wastewater $(1000 \mathrm{~mL})$, the zeolite from oil palm ash is the best ammonia removal capacity when compared with zeolite A standard and commercial zeolite.
\end{abstract}

\section{Introduction}

Palm oil has been the leading vegetable oil in term of consumption and production. Approximately 4.5 million Rai of the total area planted with oil palm in the southern Provinces of Thailand is concentrated. [1] In Thailand, more than 100,000 families of farmers was involved in oil palm cultivation and achieve annual FFB yield transported to the crude palm oil industry. The extraction of $200 \mathrm{~kg}$ of crude palm oil from fresh fruit bunch are based on the processing of $1,000 \mathrm{~kg}$ of EFB. Thus, the amount of solid waste is $750 \mathrm{~kg}$ which disposed as waste to the environmental. The high nutrients of EFB used to produce organic fertilizer. The pressed EFB can be used as fuel and mesocrap in the boiler. The heating value of EFB and mesocrap are about of 3,700 and 4,420 Kcal $/ \mathrm{kg}$ of dry fuel, respectively. [2] It is equal to $200 \mathrm{kw} / \mathrm{hr}$ and processed of EFB into pulp and paper process or fiberboard. [3] The ash of biomass is a mixture of $50-60$ of $\mathrm{SiO}_{2}$ and $2-4 \%$ of $\mathrm{Al}_{2} \mathrm{O}_{3}$ which is the alumino silicate compound. Another option for reuse of ash is silica gel and silicon carbide. On the other hand, the main composition of $\mathrm{SiO}_{2}$ and $\mathrm{Al}_{2} \mathrm{O}_{3}$ in the palm ash allow the Na-A zeolite conversion which is the promising approach to improve the palm ash utilization. Zeolite are crystalline aluminum silicate which a framework of $\mathrm{SiO}_{4}$ and $\mathrm{AlO}_{4}$ tetrahedral linked to each other at the corner via sharing their oxygen atom. The structure of three-dimensional network is made up by tetrahedral and the negatively charged lattice accounting for the substitution of $\mathrm{Si}$ by $\mathrm{Al}$ define many special properties of zeolite, such as adsorption at molecule in huge internal channels. [4] These zeolite materials are used as adsorbents for the removal of $\mathrm{NH}_{4}{ }^{+}$ion [5] and different heavy metal ions from wastewater.

Ammonia is toxic to giant fresh water prawn farm or fish if allowed to accumulate in giant fresh water prawn and fish production systems. If the ammonia concentration gets high enough $\left(1-2 \mathrm{mg} \mathrm{N} / \mathrm{dm}^{3}\right)$, the aquatic animal will be come lethargic and eventually fall and die. The relative proportion of the two forms present in water is mainly affected by $\mathrm{pH}$ and temperature following the equation (1). Unionized ammonia is the toxic form and predominates when $\mathrm{pH}$ is high. [6-7]

$$
\mathrm{NH}_{4}{ }^{+} \leftrightarrow \mathrm{NH}_{3}+\mathrm{H}^{+}
$$

Ammonium ion is relatively nontoxic and predominates when $\mathrm{pH}$ is low. The main source of ammonia in giant fresh water prawn is directly related to the feeding rate of protein level in feed. The main cause

\footnotetext{
*orresponding author: rewadee a@tistr.or.th
} 
of nitrogen pollution in aquatic system is the disposal of nutrients directly from industrial effluents or indirectly from agriculture run off such as the giant prawn fresh water feeding or fish feeding farm. Various technology treatment such as chemical precipitation, biological treatment, ion exchange, adsorption, electrochemical technology, and membrane process have been used for the removal of ammonium ions from wastewater. [8] Zeolite Na-A is known as the most value form and high cation exchang capacity.[9] Zeolite Na-A, with the $4.1 \mathrm{~A}^{\circ}$ is used for removal of ammonium ion from waste water. [10] Therefore, natural zeolite for $\mathrm{NH}_{4}{ }^{+}$removal is studied from wastewater having different composition.

In this work, we introduced mesocarp and empty fruit bunch ashes as a raw material to prepare $\mathrm{Na}-\mathrm{A}$ zeolite and used as an adsorbent to removal unionized ammonia $\left(\mathrm{NH}_{3}\right)$ from synthetic wastewater and giant fresh water prawn feeding wastewater, respectively.

\section{Methodology}

The obtain product, zeolite from oil palm ash, was prepared. The chemical structure was $\mathrm{Na}_{8} \mathrm{Al}_{6} \mathrm{Si}_{6} \mathrm{O}_{24} \mathrm{SO}_{4}$, it was dried at $105^{\circ} \mathrm{C}$ for 24 hours.

For Cation exchange capacity (CEC) values were determined using the ammonium acetate method [11]. The results were expressed as millgrams $\mathrm{CaCO}_{3}$ per gram of obtained product.

For the adsorption studies, the batch experiments for adsorption of $\mathrm{NH}_{3}$ were carried out to investigate the effect of zeolite dosage $(0.05,0.1,0.15,0.2$ and 0.25 $\mathrm{g} / 20 \mathrm{~mL}$ of synthetic waste water. (Total ammonia nitrogen: TAN in synthetic wastewater $=10 \mathrm{mg} \mathrm{N} / \mathrm{dm}^{3}$ and equal to unionized ammonia $=1.95 \mathrm{mg} \mathrm{N} / \mathrm{dm}^{3}$ ) at the $\mathrm{pH}$ value about 8.6 and $26{ }^{\circ} \mathrm{C}$, each measurement was repeated 3 times to take the average value.

Then the samples were agitated on the shaker with the speed of $120 \mathrm{rpm}$ at the room temperature and the ammonium solution was separated from the adsorbent under filtration with $0.45 \mu \mathrm{m}$ membrane filters. The initial and final ammonium concentration remaining in solution were analyzed by the standard Nesslerization method by UV spectrophotometer at $425 \mathrm{~nm}$.

The optimum for adsorbent dosage was used in the giant fresh water prawn farm to find the adsorption capacities of adsorbent. The optimum zeolite dosage was carried out to volumn of the synthetic wastewater by using zeolite A standard, zeolite from oil palm ash and commercial zeolite, respectively, for the continuous experiments.

The optimum zeolite dosage and volumn of synthetic wastewater were used in the giant fresh water prawn farm to find the adsoption capacity of various adsorbrents.

\section{Results and Discussion 3.1 Characteristic of synthetic zeolite}

The synthetic zeolite from oil palm ash (Krabi Province) was used in the experimental. The calcium exchange capacity (CEC) of zeolite A standard, zeolite from oil palm ash and commercial zeolite were approximately 420.8, 386.4 and $110 \mathrm{mg} \mathrm{CaCO}_{3} / \mathrm{g}$ zeolite product, respectively. The characteristic of the structure was analyzed using X-ray diffraction as shown in Fig.1.

The XRD pattern of the raw oil palm ash and activated oil palm ash (Fig 1.) showed that the major crystalline phases of the activated oil palm ash was kaolinite (JCPDS NO. 06-0221). The Scanning Electron Microscope (SEM) confirmed that zeolite had the cubic shape morphology as shown in Fig.2.

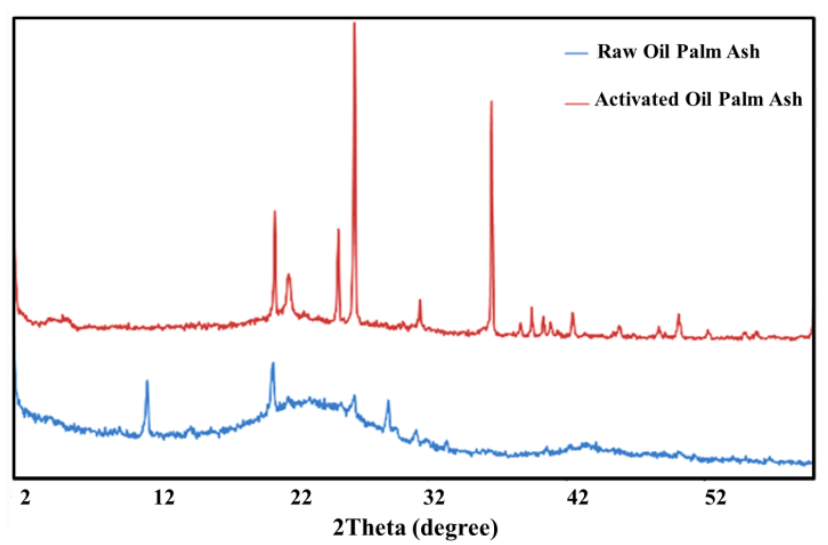

Fig1. XRD pattern of the raw oil palm ash and activated oil palm ash.

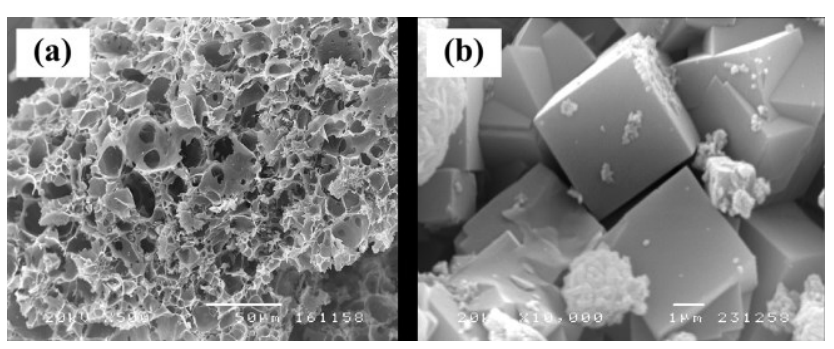

Fig 2. SEM images of (a) Raw oil palm ash and (b) Zeolite from oil palm ash.

The XRD pattern of the zeolite A standard, synthesized zeolite from oil palm ash and commercial zeolite are shown in Fig 3. It confirmed that the major crystalline phases of synthesized zeolite from oil palm ash were Sodium Aluminum Silicate Hydrate, (JCPDS NO. 11-0590).

\subsection{Unionized ammonia removal capacity}

In batch experimental study, the synthetic wastewater was prepared. The $\mathrm{pH}$ was adjusted to achieve the $\mathrm{pH}$ value of 8.6 at $26{ }^{\circ} \mathrm{C}$. In order to find out the optimal dosage of various zeolites $(0.05,0.1,0.15,0.2$ and $0.25 \mathrm{~g})$ was added into synthetic wastewater of $20 \mathrm{mg} / \mathrm{L}$ of the 
Total Ammonia Nitrogen, equal to unionized ammonia $1.95 \mathrm{mg} \mathrm{N} / \mathrm{dm}^{3}$, which were stirred for 60 minutes at $26^{\circ} \mathrm{C}$ with $120 \mathrm{rpm}$.

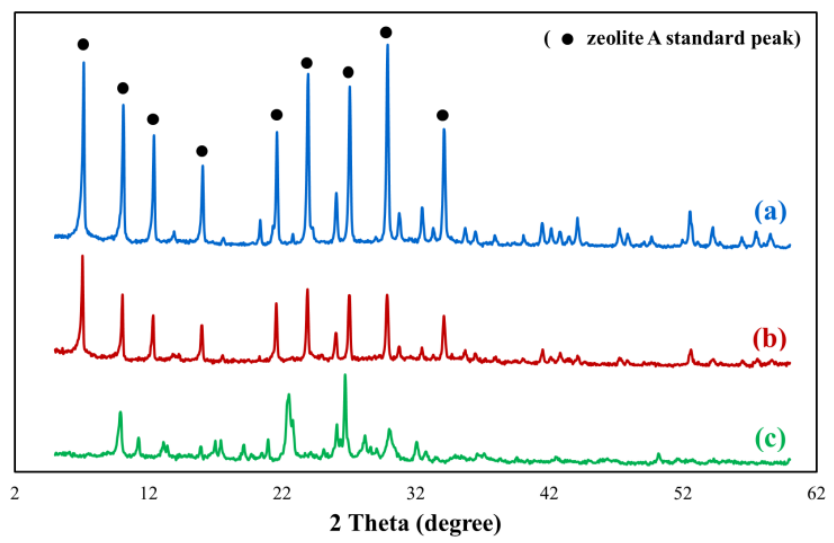

Fig 3. XRD pattern of the synthesized Na-A zeolite product from oil palm ash, (a) zeolite A standard, (b) zeolite from oil palm ash and (c) commercial zeolite

Table 1. Unionized ammonia $\left(\mathrm{NH}_{3}\right)$ removal capacity of various dosage of zeolites

\begin{tabular}{|c|c|c|c|}
\hline \multirow{2}{*}{$\begin{array}{c}\text { dosage of } \\
\text { zeolites } \\
\text { (g) }\end{array}$} & \multicolumn{3}{|c|}{$\mathrm{NH}_{3}$ removal capacity $(\%)^{*}$} \\
\hline & $\begin{array}{l}\text { zeolite A } \\
\text { standard }\end{array}$ & $\begin{array}{c}\text { zeolite } \\
\text { from oil } \\
\text { palm ash } \\
\end{array}$ & $\begin{array}{l}\text { commercial } \\
\text { zeolite }\end{array}$ \\
\hline 0.05 & $84.4 \pm 0.2$ & $83.2 \pm 0.2$ & $71.6 \pm 0.1$ \\
\hline 0.1 & $88.7 \pm 0.1$ & $88.7 \pm 0.1$ & $81.4 \pm 0.2$ \\
\hline 0.15 & $90.3 \pm 0.1$ & $90.5 \pm 0.2$ & $88.4 \pm 0.1$ \\
\hline 0.2 & $92.6 \pm 0.1$ & $90.6 \pm 0.1$ & $91.4 \pm 0.2$ \\
\hline 0.25 & $91.7 \pm 0.2$ & $91.4 \pm 0.1$ & $91.4 \pm 0.2$ \\
\hline
\end{tabular}

The average unionized ammonia $\left(\mathrm{NH}_{3}\right)$ removal capacity of various dosage of zeolites in batch experimental has shown as Table 1.The result indicated that $\mathrm{NH}_{3}$ removal capacity was not significantly different in zeolite A standard vs. zeolite from oil palm ash. The zeolite A standard and zeolite from oil palm ash are better than commercial zeolite.

For the $\mathrm{NH}_{3}$ removal capacity from giant fresh water prawn farm as shown in Table 2. The results indicated that $\mathrm{NH}_{3}$ removal capacity depended on cation exchange capacity value (CEC) because of the CEC value is representative as the amount of positive charge which can be exchanged. The result indicated that ammonia removal capacity of zeolite A standard is better than zeolite from oil palm ash and commercial zeolite respectively.
Table 2. Unionized ammonia $\left(\mathrm{NH}_{3}\right)$ removal capacity from Giant Fresh Water Prawn Farm (Initial concentration of $\mathrm{NH}_{3} 0.127 \mathrm{mgN} / \mathrm{dm}^{3}$ )

\begin{tabular}{|c|c|c|c|}
\hline Zeolite & $\begin{array}{c}\mathrm{CEC}^{*} \\
(\mathrm{mg} \\
\mathrm{CaCO}_{3} / \\
\mathrm{g} \mathrm{zeolite})\end{array}$ & $\begin{array}{c}\text { Unionized } \\
\text { ammonia } \\
\text { remain* } \\
\left(\mathrm{mgN} / \mathbf{d m}^{3}\right)\end{array}$ & $\begin{array}{c}\mathrm{NH}_{3} \\
\text { removal } \\
\text { capacity* } \\
(\%)\end{array}$ \\
\hline $\begin{array}{l}\text { zeolite A } \\
\text { standard }\end{array}$ & $420.8 \pm 0.4$ & $0.007 \pm 0.0003$ & $94.49 \pm 0.09$ \\
\hline $\begin{array}{l}\text { zeolite from } \\
\text { oil palm ash }\end{array}$ & $386.4 \pm 1.0$ & $0.010 \pm 0.0006$ & $92.13 \pm 0.17$ \\
\hline $\begin{array}{c}\text { commercial } \\
\text { zeolite }\end{array}$ & $110.0 \pm 0.8$ & $0.027 \pm 0.0015$ & $78.74 \pm 0.14$ \\
\hline
\end{tabular}

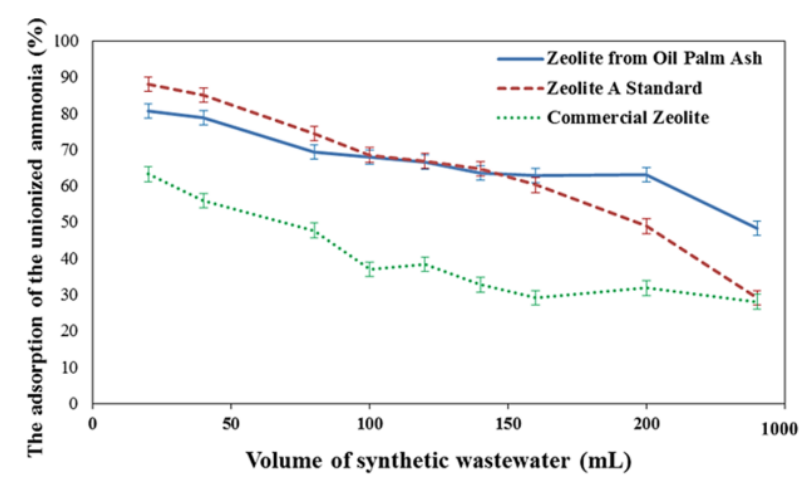

Fig 4.The adsorption of the unionized ammonia of the zeolite from oil palm ash, zeolite A standard and the commercial zeolite for the continuous experiments.

The adsorption of $\mathrm{NH}_{3}$ in continuous experiments of the volume of synthetic wastewater $(20,40,80,100,120$, $140,160,200$ and $1,000 \mathrm{~mL}$ ) indicated that in the large volume, the zeolite from oil palm ash is better than zeolite A standard and commercial zeolite, respectively as shown in Fig 4.

The zeolite from oil palm ash is better removal for the large volume of synthetic wastewater because of the various cation in composition of oil palm ash. The presence of the cation can improve the high unionized ammonia $\left(\mathrm{NH}_{3}\right)$ removal efficiency. [12]

\section{Conclusion}

The Na-A zeolite synthesis from the oil palm ash was the calcium exchange capacity (CEC) of $386.39 \mathrm{mg}$ $\mathrm{CaCO}_{3} / \mathrm{g}$ of product, and the $86.05 \%$ of pure Na-A zeolite phase was formed. The CEC of zeolite Astandard and commercial zeolite was 420.8 and $110 \mathrm{mg} \mathrm{CaCO}_{3} / \mathrm{g}$ Zeolite. The results of $\mathrm{NH}_{3}$ removal efficiency indicated that zeolite A standard and zeolite from oil palm ash are better than commercial zeolite. The $\mathrm{NH}_{3}$ removal capacity from giant freshwater prawn farm, zeolite A standard is better ammonia removal capacity than zeolite 
from oil palm ash and commercial zeolite, respectively. While, in the large volume $(1000 \mathrm{~mL})$, the zeolite from oil palm ash is the best ammonia removal capacity when compared with zeolite A standard and commercial zeolite.

\section{Acknowledgment}

The financial supports from Agricultural Research Development Agency (Public Organization) are greatly acknowledge.

\section{References}

1. Office of Agricultural Economics, Agricultural Statistics Of Thailand 2016, Thailand. (2016)

2. M. Faisal, Mahidin, Biomass Residue from Palm Oil Mills in Aceh Province: A Potential Usage for Sustainable Energy. Adv. Eng. Inf. Tech, 3 (2013)

3. M.Husin, A.Mokhtar, W. H. W.Hassan, Oil palm plywood, MPOB Information Series, 206 (2003)

4. M. Ahmaruzzaman, A review on the utilization of fly ash, Progress in Energy and Combustion Science, 36 (2010)

5. Y. Zhao, B. Zhang, X. Zhang, J. Wang, J. Liu, R. Chen, Preparation of highly ordered cubic NaA zeolite from halloysite mineral for adsorption of ammonium ions, Journal of Hazardous Materials, 178 (2010)

6. J.A. Hargreaves, C.S. Tucker, Managing Ammonia in Fish Ponds. SRAC Publication, 4603(2018)

7. D.J. Randall, T.K.N. Tsui, Ammonia toxicity in fish. Marine Pollution Bulletin, $\mathbf{4 5}$ (2002)

8. Y. Wimalasiri, M. Mossad, L. Zou, Thermodynamics andkinetics of adsorption of ammonium ions by graphene laminateelectrodes in capacitive deionization. Desalination, 357 (2015)

9. J. Izidoro, D. Fungaro, J. Abbott, S. Wang, Synthesis of zeolites X and A from fly ashes for cadmium and zinc removal from aqueous solutions in single and binary ion systems. Fuel,103 (2013)

10. D.Y. Wu, Z.B. Hu, X.Z. Wang, S.B. He, H.N. Kong, Use of zeolitized coal fly ash in the simultaneous removal of ammonium and phosphate from aqueous solution. Front Environ Sci Eng China, 1 (2007)

11. A. Molina, C. Poole, A comparative study using two methods to produce zeolite from fly ash, Miner. Eng. 17 (2004).

12. A.B.Ariffin, Production of zeolites from oil palm ash. Universiti Malaysia Pahang, Malaysia. (2010) 